\title{
OPTIMALISASI SOFT SKILL MAHASISWA AKUNTANSI UNIVERSITAS BINA NUSANTARA MELALUI EFFECTIVE TEAM BUILDING: PENDEKATAN EKSPERIMENTAL
}

\author{
Noviyanti $^{1}$; Gatot Soepriyanto ${ }^{2}$ \\ ${ }^{1,2}$ Jurusan Akuntansi, Fakultas Ekonomi dan Bisnis, Universitas Bina Nusantara \\ Jln. K.H. Syahdan No. 9, Palmerah, Jakarta Barat 11480 \\ Gsoepriyanto@binus.edu,
}

\begin{abstract}
This study aim's to analyze the differences the methods of team forming between team members selected by their own without intervention from the lecturer, the team members selected by the students themselves with the intervention from lecturer for the next phase (McGrath's model input phase), and designed team by lecturers with McGrath's model application, the establishment of this method's to determine the most effective team. Research methodology used in this study is an experimental method that targeted students who are majoring in accounting through the course of Accounting Theory and Accounting Non-Profit in the whole semester 2008/2009 in Bina Nusantara University. The statistical methods employed are simple correlation, ANOVA, Welch, Brown-Forsythe and Tamhane's T. Our research find that the most effective method is the method of team forming with the application by lecturers with McGrath's model, because the quality of the team performance leads the team into the formation of the same stage with other methods, but is able to reach the highest assignment values than other methods. In addition, the most important in forming an effective team is the quality of various inputs that will be included in the team. McGrath's application model provides the opportunity for the students to be able to work with different partners, who may not know very close each other. Therefore this method can optimize student soft skills in teamwork.
\end{abstract}

Keywords: soft skill, effective team building, McGrath model

\begin{abstract}
ABSTRAK
Penelitian ini bertujuan untuk menganalisa perbedaan metode pembentukan tim, antara tim yang anggotanya dipilih sendiri tanpa intervensi dari dosen, tim yang anggotanya dipilih sendiri oleh mahasiswa dengan intervensi dosen untuk tahapan selanjutnya (tahap input pada McGrath's Model), dan tim yang didesain oleh dosen dengan aplikasi McGrath's Model, guna menentukan metode pembentukan tim yang paling efektif. Metodologi penelitian yang digunakan adalah studi eksperimental pada pada mahasiswa-mahasiswi jurusan akuntansi yang sedang menempuh mata kuliah Teori Akuntansi dan Akuntansi Nirlaba di semester genap 2008/2009, di Universitas Bina Nusantara.. Sedangkan metode statistik yang digunakan adalah korelasi sederhana, ANOVA, Welch, Brown-Forsythe dan Tamhane's T2. Berdasarkan hasil penelitian maka dapat disimpulkan bahwa metode yang paling efektif dari ketiga metode yang telah diaplikasikan adalah metode pembentukan tim oleh dosen dengan aplikasi McGrath's Model karena dengan metode ini kualitas tim yang terbentuk memiliki kinerja dan masuk ke dalam tahapan pembentukan yang sama dengan metode lainnya namun mampu menghasilkan nilai penugasan tertinggi dibandingkan metode lainnya. Oleh karena itu, yang terpenting dalam membentuk tim yang efektif adalah kualitas dari berbagai input yang akan dimasukkan ke dalam tim. Aplikasi McGrath's Model memberi kesempatan pada para
\end{abstract}


mahasiswa untuk dapat bekerjasama dengan rekan yang berbeda, yang mungkin belum mereka kenal dekat. Sehingga, metode ini lebih bisa mengoptimalkan soft skill dalam hal teamwork.

Kata kunci: soft skill, tim yang efektif, McGrath's model

\section{PENDAHULUAN}

Perguruan tinggi merupakan salah satu institusi yang harus memperhatikan kesiapan generasi muda Indonesia untuk dapat bertahan di era globalisasi. Pendidikan akuntansi yang merupakan salah satu bagian dari perguruan tinggi, tentunya juga berkewajiban untuk berperan aktif membentuk mahasiswa agar bisa sukses di berbagai jenis profesi akuntan. Dunia kerja saat ini, termasuk untuk profesi akuntan, tidak hanya membutuhkan lulusan yang memiliki kecerdasan tinggi dalam materi kuliah (hard skill), tetapi juga membutuhkan lulusan yang memiliki kompetensi dalam bidang organisasi, kerjasama tim, kepercayaan diri, serta mampu mengendalikan emosi dalam berbagai kondisi (soft skill). Kemampuan soft skill inilah yang harus dilatih pada mahasiswa akuntansi di samping kemampuan lainnya. Salah satu cara melatih kemampuan ini adalah melalui pelatihan membentuk tim.

Universitas Bina Nusantara (BINUS) sebagai salah satu perguruan tinggi andalan Indonesia dalam membentuk sumber daya manusia yang berkualitas harus terus menerus berupaya meningkatkan kompetensi mahasiswanya. Dosen selaku fasilitator diharapkan mampu membangun tim yang efektif di dalam kelas dengan mendesain berbagai penugasan bagi para mahasiswanya. Pada dasarnya, dosen memiliki otoritas dalam mengelola kelasnya. Oleh sebab itu, seharusnya dosen dapat lebih mudah mengarahkan mahasiswanya ke arah pembentukan soft skill yang berkualitas melalui pembentukan tim kerja. Tentu saja diperlukan peran aktif mahasiswa untuk mensukseskannya. Tetapi, dosen seringkali tidak ambil pusing bagaimana mereka harus mengatur kelasnya dalam penugasan, termasuk dalam membentuk tim-tim kerja untuk suatu tugas. Untuk mempersingkat waktu atau memudahkan, seringkali dosen membiarkan pembentukan tim diatur sendiri oleh mahasiswanya. Padahal ini belum bisa dipastikan sebagai tim yang memiliki sinergi, bisa saja tim yang dibentuk mahasiswa hanyalah sebuah kelompok, bukan tim dalam arti yang sesungguhnya.

Yang menjadi masalah adalah tim yang efektif itu seperti apa? Bagaimana cara membentuk tim yang efektif? Dengan membiarkan mahasiswa memilih anggota timnya atau dosenlah yang menetapkan anggota tim dengan memperhatikan berbagai faktor (salah satu tolak ukurnya bisa melalui IPK)? Dengan meneruskan penelitian yang dilakukan oleh Tin (2007), maka riset ini dilakukan untuk menganalisa hasil pembentukan tim antara tim yang anggotanya dipilih sendiri tanpa intervensi dari dosen, tim yang anggotanya dipilih sendiri oleh mahasiswa dengan intervensi dosen untuk tahapan selanjutnya (tahap input pada McGrath's Model), dan tim yang didesain oleh dosen dengan aplikasi McGrath's Model serta membandingkan ketiga metode pembentukan tim tersebut, guna menentukan metode yang paling efektif untuk mengoptimalkan soft skill mahasiswa. Tentu saja riset ini diharapkan dapat menunjukkan efektivitas team building mahasiswa dan manfaatnya dalam mencapai hasil belajar bagi dunia pendidikan pada umumnya dan bagi dosen serta mahasiswa pada khususnya.

\section{Studi Pustaka}

Hard skill bersifat teknis dan biasanya sekedar tertulis pada biodata atau $C V$ seseorang yang mencakup pendidikan, pengalaman, dan tingkat keahlian (teknis). Sedangkan soft skill dapat dikatakan sebagai keterampilan interpersonal seperti kemampuan berkomunikasi dan bekerjasama dalam sebuah kelompok (Hermana, 2008). Kelompok berbeda dengan tim. Kelompok dapat diartikan sebagai dua individu atau lebih, yang berinteraksi dan saling bergantung untuk mencapai tujuan tertentu. 
Kelompok kerja tidak memerlukan atau tidak mempunyai kesempatan untuk terlibat dalam kerja kolektif yang menuntut upaya gabungan. Jadi, kinerja mereka hanya merupakan penggabungan dari kinerja masing-masing anggota. Tidak terdapat sinergi positif yang akan menciptakan tingkat kinerja yang lebih besar daripada jumlah input. Sementara tim kerja yaitu kelompok dimana individu dapat menghasilkan tingkat kinerja yang lebih besar daripada jumlah masukan individu tersebut (Robbins, 2006).

\section{Klasifikasi Tim}

Menurut Lasahido (2008), tim dibedakan menjadi sebagai berikut.

\section{Tim Rapuh}

Belum memiliki komitmen; masih meraba-raba dan mencari teman yang cocok; masih mencari bentuk kerangka kerja; dalam berkomunikasi lebih banyak untuk menahan diri; keterlibatannya masih taraf penjajakan; dan dalam proses belum ada pembakuan yang diberlakukan.

\section{Tim Rentan}

Komitmen mulai terbentuk; mulai memilih teman; mulai mengembangkan kerangka kerja (masih perlu arahan); komunikasi secara langsung, mulai terjadi konflik; mulai terjadi dominasi oleh sebagian anggota; serta pembakuan proses mulai berlaku, masih agak asing belum nyaman.

\section{Tim Mapan}

Sudah terbentuk komitmen; kepercayaan sudah lebih meluas, banyak diwarnai pengalaman kerja kelompok dalam tim; sudah ditemukan fokus kegiatan dan kinerja untuk mewujudkannya; komunikasi didasarkan atas kebutuhan tugas, mulai mencari mitra di luar tim; semua anggota merasa terlibat penuh; dan pada tahap proses sudah lancar, sudah menjadi "gaya" dari tim bersangkutan.

\section{Tim Matang}

Komitmen sudah meluas ke tingkat organisasi; sangat terbuka; mulai luwes terhadap perubahan dan tantangan, tim siap berinovasi; komunikasi sangat rumit, berjalan otomatis, rapat rutin mulai jarang; sudah konstan, yang tidak terkait mulai ikut terlibat, kepemimpinan muncul secara otomatis; serta pada proses penghalusan dan peningkatan mutu sudah jadi kebutuhan alami.

\section{Tim Efektif}

Memiliki komitmen yang tinggi; saling percaya satu sama lain; sepenuhnya memahami maksud dan tujuan pembentukan tim; mampu bertindak sebagai komunikator di dalam tim maupun kepada pihak lain; menjamin keterlibatan satu sama lain di dalam pengambilan keputusan bersama; dan menaati proses kegiatan yang telah disepakati bersama.

\section{Tahapan Perkembangan Tim} berikut.

Teori Bruce W. Tuckman (1960) membagi tahapan perkembangan tim menjadi sebagai

\section{Forming (Pencairan Bentuk)}


Para anggota setuju untuk bergabung dalam sebuah tim sehingga tiap orang masih membawa nilai-nilai, pendapat, dan cara kerja masing-masing. Konflik sangat jarang terjadi karena setiap orang masih sungkan dan malu-malu. Kelompok biasanya belum dapat memilih pemimpin (kecuali tim yang sudah dipilih ketua kelompoknya terlebih dahulu).

\section{Storming (Mencari Jati Diri Tim)}

Kekacauan mulai timbul. Pemimpin yang telah dipilih seringkali dipertanyakan kemampuannya dan anggota kelompok tidak ragu untuk mengganti pemimpin yang dinilai tidak mampu. Faksi-faksi sudah mulai terbentuk, terjadi pertentangan karena berbagai masalah pribadi, dan semua tidak mau kalah dengan pendapat masing-masing. Komunikasi minim karena masing-masing orang tidak mau lagi menjadi pendengar dan sebagian lagi tidak mau berbicara secara terbuka.

\section{Norming}

Tiap anggota mulai merasakan keuntungan bekerja bersama dan berjuang untuk menghindari tim tersebut dari kehancuran. Anggota mulai merasa bebas mengungkapkan perasaan dan pendapatnya karena semangat kerjasama sudah mulai timbul. Selain itu, semua orang mulai mau menjadi pendengar yang baik. Seluruh anggota menetapkan dan menaati mekanisme kerja dan aturan-aturan main.

\section{Performing (Tim Mulai Menunjukkan Kinerja)}

Tahapan performing merupakan titik kulminasi dimana tim telah berhasil membangun sistem yang memungkinkannya untuk dapat bekerja secara produktif dan efisien. Pada tahapan ini pula, keberhasilan tim akan terlihat dari prestasi yang ditunjukkan.

Pada tahun 1997, Tuckman menambahkan tahapan pembentukan tim yang kelima adalah adjourning. Ini merupakan tahapan membubarkan diri sebuah tim. Penelitian ini selanjutnya hanya akan menggunakan 4 tahapan utama pembentukan tim karena penelitian ini tidak mengamati proses pembubaran tim.

\section{McGrath's Model of Group Effectiveness}

McGrath's model pada tahap inputnya menekankan pada kualitas dari berbagai input yang akan dimasukkan ke dalam tim. Faktor-faktornya antaralain individual-level factors, group-level factors, dan environment-level factors. Individual-level factors mencakup keahlian /kemampuan anggota (yang dapat dilihat melalui IPK) serta sikap dan ciri kepribadian anggota (terkait rasa suka atau tidak suka seseorang bekerja dalam sebuah kelompok. Group-level factor mencakup struktur (berhubungan dengan budaya, gender, dan cara pembentukan tim), tingkat kepaduan (kontrak tim merupakan alat paling efektif bagi tim untuk membentuk komitmen), dan ukuran tim (4-7 orang merupakan ukuran yang ideal). Sedangkan environment-level factor berkaitan dengan karakteristik tugas (apakah tugas tersebut cocok dikerjakan secara individual atau lebih cocok dikerjakan secara tim), struktur penghargaan, dan tingkat tekanan lingkungan (tekanan waktu dan kesulitan melakukan pekerjaan). Struktur penghargaan dibedakan menjadi group-only model (kinerja kelompok dinilai dengan sebuah angka tunggal yang diberikan pada seluruh anggota kelompok) dan mixed-incentive model (skor yang diberikan tergantung pada hasil evaluasi terhadap usaha individu tiap anggota dan dikombinasikan dengan skor kelompok). Untuk mengatasi kesulitan pekerjaan yang dilakukan mahasiswa dosen seharusnya mengarahkan tugas mereka.

Pada tahap proses, tim mencoba untuk berinteraksi antar anggota secara efektif dan efisien. Kendala utama pada tahap ini adalah mengenai konflik interpersonal. Semakin besar tim, semakin banyak jenis kepribadian dan variasi waktu yang harus diakomodasi dan semakin banyak pula konflik 
yang akan dihadapi. Tahap proses meliputi bagaimana anggota mengatasi konflik, sehingga yang perlu diperhatikan adalah bagaimana tim menjadikan konflik sebagai kesuksesan (Tin, 2007). Tahap output, fokus tim yang sukses terletak pada hasil yang ingin dicapai. Rencana kerja membantu memastikan tiap anggota tetap fokus pada tugas dan mencapai tujuan (Tin, 2007). Menurut McGrath (1964), hasil kinerja merupakan faktor ekstrinsik yang mencakup kualitas, kecepatan, dan jumlah kesalahan dari hasil. Hasil lainnya adalah kepuasan anggota, keterpaduan kelompok, dan perubahan sikap.

\section{METODE PENELITIAN}

Penelitian ini akan diadakan di Universitas Bina Nusantara, Jakarta, dari 24 Februari 2009 hingga 20 Juni 2009. Objek penelitian ini adalah mahasiswa-mahasiswi jurusan akuntansi yang sedang menempuh mata kuliah Teori Akuntansi dan Akuntansi Nirlaba di semester genap 2008/2009, di Universitas Bina Nusantara. Data dalam penelitian ini bersumber dari data primer (berupa input mahasiswa untuk suatu pembentukan tim) dan data sekunder (daftar mahasiswa beserta data IPK mahasiswa). Penentuan sampel dilakukan dengan menggunakan teknik purposive sampling berbasis nonprobability. Karena penelitian ini merupakan penelitian pendidikan akuntansi maka sampel yang dipilih adalah mahasiswa akuntansi. Pengumpulan data pada penelitian ini menggunakan teknik observasi dan kuesioner. Metode analisis data yang digunakan adalah korelasi sederhana, ANOVA, Welch, Brown-Forsythe, Tamhane's T2, Dunnett's T3, Games Howell, dan Dunnett's C yang diolah dengan program SPSS.

\section{Pengembangan Hipotesis}

Faktor kedekatan yang terjadi pada tim yang anggotanya dipilih sendiri tanpa intervensi dari dosen dan tim yang anggotanya dipilih sendiri oleh mahasiswa dengan intervensi dosen untuk tahapan selanjutnya (tahap input pada McGrath's Model) dapat menyebabkan antar anggota saling sungkan untuk menegur rekan kerjanya jika melanggar tanggung jawabnya, namun kedekatan itu bisa memudahkan mereka dalam bekerjasama. Tetapi tim yang anggotanya dipilih sendiri tanpa intervensi dari dosen memiliki peluang untuk tidak mempunyai komitmen dan pembagian tugas yang jelas karena tidak terikat kontrak kerja atau rencana kerja. Tim yang didesain oleh dosen dengan aplikasi McGrath's Model, mempertimbangkan faktor input yang dimasukkan ke dalam tim. Adanya kontrak kerja dan rencana kerja membuat anggota tim lebih berkomitmen terhadap tim. Namun, desain tim seperti ini dapat memungkinkan antar anggota tim kurang cocok atau belum dapat saling beradaptasi karena anggota tim belum pernah bekerja sama sebelumnya.

Perbedaan desain tim tersebut dapat menghasilkan output (kinerja tim) yang berbeda tetapi tidak menutup kemungkinan output yang dihasilkan akan sama. Maka munculah hipotesis sebagai berikut (dinyatakan dalam hipotesis alternatif):

$\mathrm{H}_{\mathrm{A} 1}$ : Terdapat perbedaan hasil kinerja tim antara tim yang anggotanya dipilih sendiri tanpa intervensi dari dosen, tim yang anggotanya dipilih sendiri oleh mahasiswa dengan intervensi dosen untuk tahapan selanjutnya (tahap input pada McGrath's Model), dan tim yang didesain oleh dosen dengan aplikasi McGrath's Model.

Kinerja tim dapat mempengaruhi hasil penugasan. Rencana kerja dapat membantu memastikan tiap anggota tetap fokus pada tugas untuk mencapai tujuan. Keberhasilan hasil penugasan bisa dilihat dari kualitas, kecepatan, dan jumlah kesalahan dari hasil. Desain tim tentu saja terkait dengan hal-hal tersebut. Desain tim yang berbeda mungkin menghasilkan hasil penugasan yang 
berbeda pula atau malah sama. Oleh karena itu, hipotesis kedua penelitian ini adalah (dinyatakan dalam hipotesis alternatif):

$\mathrm{H}_{\mathrm{A} 2}$ : Terdapat perbedaan hasil penugasan atas metode pembentukan tim antara tim yang anggotanya dipilih sendiri tanpa intervensi dari dosen, tim yang anggotanya dipilih sendiri oleh mahasiswa dengan intervensi dosen untuk tahapan selanjutnya (tahap input pada McGrath's Model), dan tim yang didesain oleh dosen dengan aplikasi McGrath's Model.

Menurut Lasahido (2008) tim dapat diklasifikasikan menjadi tim rapuh, rentan, mapan, matang, dan efektif. Umumnya orang berpendapat bahwa kualitas tim yang baik akan menghasilkan hasil penugasan yang baik. Padahal selain anggota tim itu sendiri, tidak ada yang mengetahui secara mendalam bagaimana kinerja tim tersebut. Mungkin saja kinerja tim yang kurang baik tetap bisa menghasikan output yang sama baiknya dengan kinerja tim yang baik, karena mungkin hanya satu pihak yang mengerjakan penugasan tersebut dengan kemampuannya yang tinggi. Oleh karena itu, hipotesis ketiga dari penelitian ini, yang dinyatakan dalam hipotesis alternatif adalah sebagai berikut:

$\mathrm{H}_{\mathrm{A} 3}$ : Terdapat hubungan antara hasil kinerja tim dengan hasil penugasan.

Teori Bruce W. Tuckman (1960) menyatakan bahwa tahapan perkembangan tim dibagi menjadi tahap forming, storming, norming, dan performing. Setiap tim yang dibentuk dapat dikategorikan sebagai salah satu dari tahapan perkembangan tim tersebut. Oleh karena itu, setiap tim yang terbentuk dengan model yang berbeda-beda mungkin masuk dalam kategori yang berbeda pula. Masing-masing tahapan pembentukan tim memiliki kecenderungan yang berbeda baik dalam bekerjasama, berinteraksi, maupun dalam menyelesaikan konflik dengan rekan timnya, sehingga output masing-masing tim mungkin berbeda pula. Yang dimaksud output pada penelitian ini adalah berupa hasil penugasan. Maka, hipotesis keempat ini (dinyatakan dalam hipotesis alternatif) adalah:

$\mathrm{H}_{\mathrm{A} 4}$ : Terdapat hubungan antara tahapan pembentukan tim dengan hasil penugasan.

\section{HASIL DAN PEMBAHASAN}

Penelitian dilaksanakan pada 131 mahasiswa yang terbagi dalam dua kelas jurusan akuntansi Universitas Bina Nusantara. Selama satu semester yang terdiri dari 13 pertemuan (13 minggu), mahasiswa diberi tugas oleh dosen untuk membuat tiga paper dengan metode pembentukan tim yang berbeda-beda, namun dengan tingkat kesulitan dan waktu penyelesaian yang sama (3 minggu). Setiap tim terdiri dari 4-6 orang. Mereka mengerjakan paper tersebut bersama tim mereka. Paper pertama diselesaikan dengan metode sendiri yang berarti pembentukan anggota tim dipilih sendiri oleh mahasiswa tanpa intervensi dosen. Mahasiswa mengerjakan paper tersebut dengan aturan dan cara mereka sendiri. Metode yang kedua ini akan disebut sebagai metode sendiri ++ , dimana pembentukan anggota tim dipilih sendiri oleh mahasiswa dengan intervensi dosen untuk tahap selanjutnya (tahap proses pada McGrath's model).

Pada awal pembentukan tim, dosen meminta tim-tim membuat kontrak tim dan rencana tim. Kontrak tim berisi kesepakatan tim dalam menyelesaikan tugas, ditandatangani dosen dan para anggota tim. Rencana kerja berisi apa saja yang akan dilakukan tim dalam menyelesaikan tugas. Dosen juga menyatakan secara lisan kesediaannya untuk memberi konsultasi mengenai paper yang mereka buat. Dosen memberikan reward kepada tim-tim atas hasil penugasan. Untuk yang terbaik diberikan hadiah dan pujian. Sebaliknya untuk yang masih kurang, dosen membahas apa yang menjadi kesalahan dalam tugas mereka dan dosen menanyakan apa saja yang menjadi masalah tim-tim tersebut sehingga hasilnya kurang memuaskan. Untuk penugasan ketiga, tim dibentuk oleh dosen dengan 
pertimbangan keseimbangan IPK, gender, sifat mahasiswa yaitu tentang suka atau tidak suka bekerja dalam tim, dan aspirasi mereka mengenai rekan kerja yang diinginkan dan yang tidak diinginkan (metode McGrath's). Setelah tim dibentuk, dosen melakukan hal-hal yang sama dengan metode sendiri ++ , baik tentang pembuatan kontrak tim, rencana tim, konsultasi, maupun reward.

Pada akhir tiap penugasan, tiap mahasiswa diminta mengisi kuesioner. Ada dua kuesioner yang digunakan pada penelitian ini (sumber Tim Maxi Plus) yaitu Team Performance Questionaire untuk mengetahui kinerja sebuah tim dan Team Work Questionaire untuk mengetahui pada tahapan mana tim berada. Jadi, ada 3 kali pengisian kuesioner yang sama sehingga secara keseluruhan ada 393 Team Performance Questionaire dan 393 Team Work Questionaire yang dibagikan. Namun, kuesioner yang berhasil terkumpul adalah 385 Team Performance Questionnaire dan 385 Team Work Questionnaire . Kedua kuesioner tersebut telah lolos pengujian validitas dan reliabilitas.

Data yang diolah adalah hasil kuesioner yang telah dirata-rata untuk tiap tim. Secara keseluruhan untuk masing-masing metode pembentukan tim ada 23 tim yang diuji. Karena uji ANOVA mensyaratkan bahwa skala pengukuran yang digunakan paling tidak interval, data harus berdistribusi normal dan dipenuhinya asumsi homogenitas varian maka berdasarkan hasil pengujian yang telah dilakukan pada hasil Team Performance Questionaire, semua asumsi tersebut telah terpenuhi. Oleh karena itu, pengujian ANOVA dengan menggunakan uji $\mathrm{F}$ bisa dilakukan pada hipotesis pertama.

Hipotesis kedua menggunakan uji Welch dan Brown-Forsythe karena asumsi homogenitas varian tidak terpenuhi. Sedangkan pengujian lanjut untuk menguji perbandingan secara berpasangan menggunakan Tamhane's T2, Dunnett's T3, Games Howell, dan Dunnett's C. Sedangkan hipotesis ketiga dan keempat menggunakan Pearson Correlation.

\section{Analisis Hasil Pengujian Hipotesis Pertama}

Rata-rata nilai hasil kinerja dengan menggunakan metode sendiri adalah 64,83 dengan deviasi standar sebesar 7,849. Untuk metode sendiri ++ rata-rata nilai hasil kinerja adalah 64,43 dengan deviasi standar sebesar 6,618. Sedangkan metode McGrath menghasilkan rata-rata nilai hasil kinerja sebesar 62,91 dengan deviasi standar 6,598. Terlihat bahwa metode sendiri memiliki rata-rata hasil kinerja tim lebih baik dari metode lainnya walaupun perbedaannya tidak signifikan.

Tabel 1 Statistik Deskriptif Hasil Kinerja Tim dengan Tiga Metode

\begin{tabular}{cccc}
\hline Metode & Total Tim & Mean & Std. Deviation \\
\hline Sendiri & 23 & 64,83 & 7,849 \\
Sendiri ++ & 23 & 64,43 & 6,618 \\
McGrath & 23 & 62,91 & 6,598 \\
Total & 69 & 64,06 & 6,991 \\
\hline
\end{tabular}

Sementara itu hasil pengujian hipotesisnya adalah sebagai berikut:

Tabel 2 Hasil Pengujian Tiga Metode dengan ANOVA

\begin{tabular}{cc}
\hline $\mathrm{F}$ & SIG. \\
\hline 0,473 & 0,625 \\
\hline
\end{tabular}


Hasil perhitungan menunjukkan nilai $\mathrm{F}$ hitung adalah 0,473 dengan nilai signifikansi sebesar 0,625. Dengan alpha 5\%, tiga metode yang digunakan, dan jumlah sample terdiri dari 69 sampel, maka:

$$
\begin{aligned}
\mathrm{F}_{\text {tabel }} & =\mathrm{F}_{\alpha ;(\mathrm{k}-1) ; \mathrm{k}(\mathrm{n}-1)} \\
& =\mathrm{F}_{0.05 ;(3-1) ; 3(69-1)} \\
& =\mathrm{F}_{0.05 ; 2 ; 204} \\
\mathrm{~F}_{\text {tabel }} & =3,04
\end{aligned}
$$

Dari hasil tersebut, nilai F hitung lebih kecil dari F tabel. Maka, keputusan yang dapat diambil adalah $\mathrm{H}_{\mathrm{A} 1}$ ditolak. Sehingga, kesimpulan yang diperoleh adalah tidak terdapat perbedaan hasil kinerja tim antara tim yang anggotanya dipilih sendiri tanpa intervensi dari dosen, tim yang anggotanya dipilih sendiri oleh mahasiswa dengan intervensi dosen untuk tahapan selanjutnya (tahap input pada McGrath's Model), dan tim yang didesain oleh dosen dengan aplikasi McGrath's Model. Metode sendiri dan sendiri ++ cenderung memilih rekan tim yang sudah mereka kenal dekat sehingga mereka lebih mudah.

Jumlah mahasiswa jurusan akuntansi Universitas Bina Nusantara untuk tiap tahun ajaran baru tidak terlalu banyak, sehingga pada umumnya mahasiswa saling mengenal walau tidak semuanya dekat. Dengan demikian, ketika dosen membagi mereka ke dalam tim, baik dipilih sendiri maupun tidak, mereka tidak terlalu mengalami kesulitan untuk bekerjasama. Jelas terlihat bahwa kinerja tim yang mereka bentuk, baik dipilih sendiri maupun tidak, tetap bisa menghasilkan kinerja yang sama baiknya. Ketiga metode yang berbeda tersebut rata-rata sama-sama menghasilkan tim yang matang walau dari ketiga metode tersebut belum bisa diklasifikasi sebagai tim yang efektif. Metode sendiri memang tidak membuat kontrak tim dan rencana kerja secara tertulis. Namun, biasanya mereka sudah memiliki cara dan aturan sendiri sesuai dengan pengalaman bekerjasama mereka sebelumnya. Sehingga aturan dan cara tersebut lebih bersifat lisan dan tidak dibicarakan lebih detail karena mereka sudah saling mengerti. Ketika metode sendiri ++ diterapkan, mereka hanya tinggal menuliskan apa yang menjadi aturan dan cara mereka bekerja selama ini secara tertulis dan lebih formal ke dalam suatu kontrak tim dan rencana kerja. Maka, jelas bahwa kinerja tim dengan kedua metode tersebut tidak berbeda.

Pada aplikasi metode McGrath, antar anggota dalam tiap tim tidak semuanya pernah bekerjasama sebelumnya. Pada saat proses pembuatan kontrak tim dan rencana tim, mereka memiliki kesempatan untuk saling mengenal lebih dekat dan membuat kesepakatan yang akan ditetapkan selama proses penyelesaian tugas. Karena ada kesepakatan yang jelas inilah, antar anggota tim memiliki satu tujuan yang sama. Sehingga mereka dapat bekerjasama dengan baik sesuai kesepakatan bersama. Selain itu, karena antara mereka ada yang belum dekat, mereka lebih menghormati satu sama lain. Maka, kesepakatan yang telah dibuat berusaha diterapkan sebaik mungkin. Oleh karena itu, tidak mengherankan jika tim-tim dengan metode McGrath juga memiliki kinerja yang sama baik dengan tim yang terbentuk dengan metode sendiri dan sendiri ++. Dalam proses pengerjaan tugas, biasanya sering timbul konflik. Dari ketiga metode yang ada, ternyata mahasiswa sama-sama bisa menyelesaikan konflik yang terjadi dengan baik. Metode sendiri dan sendiri ++ karena mereka sudah saling mengenal maka tentu saja mereka dapat menyelesaikan konflik dengan baik. Begitu juga dengan metode McGrath, tim dapat menyelesaikan konflik karena mereka memiliki rasa saling menghormati yang tinggi atas dasar mereka baru saling dekat. 


\section{Analisis Hasil Pengujian Hipotesis Kedua}

Tabel 3 Deskriptif Statistik Perbandingan Tiga Metode

\begin{tabular}{cccc}
\hline Metode & Mean & Std. Deviation & Std.Error \\
\hline Sendiri & 65,1087 & 15,04479 & 3,13705 \\
Sendiri ++ & 64,3913 & 19,04478 & 3,97111 \\
McGrath & 78,0870 & 8,01086 & 1,67038 \\
\hline
\end{tabular}

Dari statistik deskriptif menunjukkan bahwa rata-rata hasil penugasan metode McGrath lebih tinggi dari metode lainnya, sedangkan metode sendiri ++ memiliki rata-rata nilai paling rendah.

Tabel 4 Pengujian Statistik Tiga Metode

\begin{tabular}{ccc}
\hline Test & Statistic & Sig. \\
\hline Welch & 9,766 & 0,000 \\
Brown-Forsythe & 6,277 & 0,004 \\
\hline
\end{tabular}

Dengan menggunakan uji Brown-Forsythe dan uji Welch, hasil analisis menunjukkan nilai statistic Welch test adalah 9,766 dengan signifikansi sebesar 0,000. Nilai statistik untuk BrownForsythe adalah 6,277 dengan signifikansi 0,004. Baik Welch test maupun Brown-Forsythe, memiliki nilai signifikansi yang lebih kecil dari nilai alpha (5\%) sehingga keputusan yang diambil adalah $\mathrm{H}_{\mathrm{A} 2}$ diterima. Maka, kesimpulan dari pengujian hipotesis ini adalah terdapat perbedaan hasil penugasan atas metode pembentukan tim antara tim yang anggotanya dipilih sendiri tanpa intervensi dari dosen, tim yang anggotanya dipilih sendiri oleh mahasiswa dengan intervensi dosen untuk tahapan selanjutnya (tahap input pada McGrath's Model), dan tim yang didesain oleh dosen dengan aplikasi McGrath's Model.

Kesimpulan dari pengujian hipotesis kedua adalah terdapat perbedaan hasil penugasan atas metode pembentukan tim antara tim yang anggotanya dipilih sendiri tanpa intervensi dari dosen, tim yang anggotanya dipilih sendiri oleh mahasiswa dengan intervensi dosen untuk tahapan selanjutnya (tahap input pada McGrath's Model), dan tim yang didesain oleh dosen dengan aplikasi McGrath's Model. Rata-rata hasil penugasan metode McGrath adalah yang paling tinggi dan perbedaan nilai dengan metode lainnya cukup signifikan. Metode McGrath, pembentukan timnya dilakukan oleh dosen dengan mempertimbangkan berbagai faktor yaitu keseimbangan IPK, gender, sifat suka atau tidak suka bekerja dalam tim, maupun asprirasi mahasiswa atas keinginannya untuk bekerja dengan seseorang yang paling disenangi dan ketidakinginannya bekerja dengan orang yang tidak ia sukai. Tim-tim yang terbentuk memiliki rata-rata kualitas yang sama. Mahasiswa yang IPKnya tertinggi dalam tiap tim ditetapkan sebagai ketua tim, dengan harapan mahasiswa tersebut dapat mengarahkan anggota tim lainnya untuk menghasilkan output penugasan yang baik.

Metode McGrath juga mengharuskan tiap tim untuk membuat kontrak tim dan rencana tim sehingga mereka lebih berkomitmen dan terarah dalam proses pengerjaan tugas. Karena umumnya dalam tiap anggota ada yang belum pernah bekerjasama sebelumnya, maka mereka lebih merasa sungkan dan malu bila mereka tidak menjalankan kesepakatan yang telah mereka buat. Mereka merasa memiliki rasa tanggung jawab yang lebih tinggi dan ingin menghasilkan kualitas pekerjaan terbaik mereka agar tidak dianggap buruk bila mengerjakan sesuatu yang tidak maksimal. 
Berdasarkan data aspirasi mahasiswa, ternyata mahasiswa di dua kelas ini hanya sebagian kecil yang tidak suka bekerja dalam tim sehingga tidak menjadi masalah yang sangat signifikan dalam memberi penugasan dalam tim. Dalam proses pengerjaan tugas, tim-tim pun berkonsultasi dengan dosen mengenai kesulitan yang mereka alami. Ini juga yang dapat menyebabkan hasil penugasan dengan metode ini baik.

Sebaliknya, metode sendiri dan sendiri ++ memiliki rata-rata hasil penugasan lebih rendah secara signifikan dibandingkan dengan metode McGrath. Namun, perbedaan antara metode sendiri dan sendiri ++ tidaklah signifikan. Hal ini dikarenakan tim-tim dibentuk berdasarkan faktor kedekatan yang sangat tinggi. Sehingga baik diberi treatment maupun tidak, hasil yang mereka dapatkan tidak jauh berbeda. Kesepakatan mudah saja dilanggar tanpa rasa sungkan antar anggota. Anggota lainnya juga merasa berat menegur rekan yang lalai dalam tanggung jawab karena mereka merasa tidak enak bila menyinggung perasaan rekannya itu. Yang lebih diperhatikan dalam pembentukan tim ini adalah perasaan antar tim bukan hasil yang dicapai tim.

Selain itu, karena tidak memperhatikan keseimbangan IPK maka tim-tim yang terbentuk tidak memiliki kualitas yang sama. Hasil penugasan pun menjadi tidak seimbang. Maka ketika rata-rata IPK kelas rendah, hanya sedikit tim yang memiliki rata-rata IPK cukup tinggi, sehingga rata-rata hasil penugasan dengan kedua metode ini menjadi cenderung rendah. Metode sendiri ++ memang memberi kesempatan bagi tiap tim untuk berkonsultasi dengan dosen, namun tidak menjadikan metode ini menghasilkan rata-rata penugasan yang lebih baik dibanding metode McGrath, malahan metode sendiri ++lah yang rata-rata hasil penugasannya terendah. Tim-tim yang terbentuk dengan metode sendiri ++ , berusaha menaati apa yang telah disepakati selama proses pengerjaan. Mereka lebih fokus pada aturan daripada output yang dihasilkan. Tim yang memiliki rata-rata IPK tinggi bisa saja tetap memperhatikan output dan aturan yang ada. Namun, tim yang IPK rata-ratanya rendah terkadang tidak sanggup memperhatikan keduanya sekaligus. Matriks waktu yang telah mereka sepakati sangat mereka junjung sehingga yang lebih mereka perhatikan adalah ketepatan waktu, bukan kualitas output. Yang penting mengerjakan tugas dengan aturan dosen dengan kualitas apapun daripada tidak mengumpulkan dan mengikuti kemauan dosen. Ini yang menyebabkan rata-rata penugasan dengan metode sendiri ++ rendah.

Demikian juga dengan rata-rata hasil penugasan dengan metode sendiri, karena anggota timnya sama dengan metode sendiri ++ , maka rata-rata hasil penugasan keduanya sama saja walau metode sendiri menghasilkan nilai yang sedikit lebih tinggi. Hal ini dikarenakan tim tidak harus memperhatikan kesepakatan tim sehingga mereka tidak terlalu merasa terbebani dengan aturan. Apa yang perlu akan mereka bicarakan secara langsung.

\section{Analisis Hasil Pengujian Hipotesis Ketiga}

Pengujian dilakukan dengan menggunakan semua data rata-rata tim yang ada, baik dengan metode sendiri, sendiri ++, maupun McGrath, yang berarti ada 69 data tim yang diuji. Berikut ini merupakan hasil pengujian antara hasil kinerja tim dengan hasil penugasan:

Tabel 5 Hasil Pengujian antara Hasil Kinerja Tim dan Hasil Penguasan

\begin{tabular}{|c|c|c|c|}
\hline & & $\begin{array}{c}\text { Hasil } \\
\text { Kinerja }\end{array}$ & $\begin{array}{c}\text { Hasil } \\
\text { Penugasan }\end{array}$ \\
\hline Hasil Kinerja & $\begin{array}{l}\text { Pearson Correlation } \\
\text { Sig. (2-tailed) }\end{array}$ & 1 & $\begin{array}{l}0,055 \\
0,653\end{array}$ \\
\hline Hasil Penugasan & $\begin{array}{l}\text { Pearson Correlation } \\
\text { Sig. (2-tailed) }\end{array}$ & $\begin{array}{l}0,055 \\
0,653\end{array}$ & 1 \\
\hline
\end{tabular}


Dari hasil output terlihat bahwa nilai koefisien korelasi antara hasil kinerja dengan hasil penugasan adalah 0,055 . Nilai koefisien korelasi ini tidak signifikan dan menunjukkan korelasi yang lemah atau tidak ada korelasi antar dua variabel tersebut. Dari hasil output terlihat bahwa nilai sig adalah 0,653. Jika nilai sig dibandingkan dengan alpha (5\%), maka keputusan yang diambil adalah $\mathrm{H}_{\mathrm{A} 3}$ ditolak. Dengan keputusan ini, kesimpulan yang dapat diperoleh adalah tidak terdapat hubungan antara hasil kinerja tim dengan hasil penugasan.

Untuk mengetahui metode mana yang memungkinkan adanya korelasi antara hasil kinerja dengan hasil penugasan, maka dilakukan pengujian korelasi untuk masing-masing metode. Di bawah ini merupakan hasil yang diperoleh dari pengujian tersebut:

Tabel 6 Korelasi antara Hasil Kinerja dan Hasil Penugasan

\begin{tabular}{cccc}
\hline Metode & Sendiri & Sendiri ++ & McGrath \\
\hline Pearson Correlation & $-0,008$ & 0,306 & $-0,056$ \\
Sig. (2-tailed) & 0,972 & 0,156 & 0,801 \\
\hline
\end{tabular}

Dari hasil tersebut, terlihat bahwa dari ketiga metode yang diterapkan, tidak ada satu pun metode yang menunjukkan bahwa antara hasil kinerja dengan hasil penugasan memiliki korelasi. Nilai signifikansi lebih besar dari nilai alpha.

Kesimpulan yang diperoleh dari hipotesis ketiga adalah tidak terdapat hubungan antara hasil kinerja tim dengan hasil penugasan. Umumnya kinerja tim berhubungan dengan kualitas output yang dihasilkan. Pada penelitian ini ternyata hal itu tidak memiliki korelasi. Tim-tim yang ada memiliki kinerja tim yang baik yaitu rata-rata masuk dalam klasifikasi tim-tim yang matang. Namun, kinerja tim-tim yang baik tersebut tidak semuanya menghasilkan output yang berkualitas. Beberapa tim yang tidak menghasilkan nilai penugasan yang baik karena faktor rata-rata IPK mereka cenderung rendah, tetap merasa kinerja tim mereka telah sangat baik karena mereka bekerja dengan kualitas yang cenderung sama antar rekan kerja. Mereka tidak merasa tertekan karena tidak ada paksaan untuk bekerja jauh dari kemampuan mereka. Demikian juga dengan tim yang rata-rata IPKnya tinggi, timtim tersebut juga bekerja dengan kualitas mereka. Karena pada umumnya tim yang memiliki rata-rata IPK tinggi menginginkan nilai yang terbaik, maka mereka umumnya bekerja dengan kualitas terbaik mereka. Pemilihan rekan yang seimbang membuat mereka memiliki kinerja tim yang baik pula karena terhindar dari rekan kerja yang jauh di bawah kualitas mereka.

\section{Analisis Hasil Pengujian Hipotesis Keempat}

Setelah poin dari masing-masing pertanyaan diperoleh, maka masing-masing pertanyaan diklasifikasikan sesuai kriteria sistem klasifikasi tahapan pembentukan tim yang telah dijelaskan di bagian sebelumnya. Hasil individu tersebut kemudian dirata-rata sesuai tim masing-masing mahasiswa. Sehingga ada 69 data, yang masing-masing metode terdiri dari 23 data. Setelah didapat hasil yang menunjukkan tahapan sebuah tim, selanjutnya tahapan tersebut diberi bobot sesuai ketentuan di bawah ini:

Tabel 7 Bobot Hasil Tahapan Tim

\begin{tabular}{lc}
\multicolumn{1}{c}{ Tahapan Tim } & Bobot \\
\hline Forming & 1 \\
Storming & 2 \\
Norming & 3 \\
Performing & 4 \\
\hline
\end{tabular}


Pengujian korelasi dilakukan untuk menguji hipotesis keempat, yaitu:

$\mathrm{H}_{\mathrm{A} 4}$ : Terdapat hubungan antara tahapan pembentukan tim dengan hasil penugasan.

Berikut ini adalah hasil uji korelasi antara tahapan pembentukan tim dengan hasil penugasan untuk 69 data secara keseluruhan:

Tabel 8 Hasil Uji Korelasi antara Pembentukan Tim dengan Hasil Penugasan

\begin{tabular}{|c|c|c|c|}
\hline & & $\begin{array}{c}\text { Tahapan } \\
\text { Pembentukan Tim }\end{array}$ & $\begin{array}{c}\text { Hasil } \\
\text { Penugasan }\end{array}$ \\
\hline Tahapan & Pearson Correlation & 1 & 0,203 \\
\hline Pembentukan Tim & Sig. (2-tailed) & & 0,094 \\
\hline \multirow[t]{2}{*}{ Hasil Penugasan } & Pearson Correlation & 0,203 & 1 \\
\hline & Sig. (2-tailed) & 0,094 & \\
\hline
\end{tabular}

Dari hasil output terlihat bahwa nilai koefisien korelasi antara tahapan pembentukan tim dengan hasil penugasan adalah 0,203. Nilai koefisien korelasi ini tidak signifikan dan menunjukkan korelasi yang lemah atau tidak ada korelasi antar dua variabel tersebut. Dari hasil output terlihat bahwa nilai sig adalah 0,094. Jika nilai sig dibandingkan dengan alpha (5\%), maka keputusan yang diambil adalah $\mathrm{H}_{\mathrm{A} 4}$ ditolak. Dengan keputusan ini, kesimpulan yang dapat diperoleh adalah tidak terdapat hubungan antara tahapan pembentukan tim dengan hasil penugasan. Untuk mengetahui metode mana yang memungkinkan terjadinya korelasi antara tahapan pembentukan tim dengan hasil penugasan, maka dilakukan uji korelasi untuk masing-masing metode. Berikut ini merupakan hasil pengujian tersebut:

Tabel 9 Korelasi antara Tahapan Pembentukan Tim dan Hasil Penugasan

\begin{tabular}{cccc}
\hline Metode & Sendiri & Sendiri ++ & McGrath \\
\hline Pearson Correlation & $-0,075$ & 0,428 & 0,005 \\
Sig. (2-tailed) & 0,735 & 0,042 & 0,983 \\
\hline
\end{tabular}

Metode sendiri dan metode McGrath memiliki nilai sig yang lebih besar dari nilai alpha (5\%), maka pada kedua metode tersebut tidak terjadi korelasi antara tahapan pembentukan tim dengan hasil penugasan. Tetapi pada metode sendiri ++, nilai sig lebih kecil dari nilai alpha, maka pada metode ini terjadi korelasi antara tahapan pembentukan tim dengan hasil penugasan. Dan hubungan yang terjadi adalah hubungan positif, artinya semakin tinggi tahapan pembentukan tim maka semakin tinggi pula hasil penugasan tim.

Secara umum, kesimpulan yang dapat diperoleh dari hasil pengujian adalah tidak terdapat hubungan antara tahapan pembentukan tim dengan hasil penugasan. Sama seperti kinerja tim, ternyata hasil penugasan tidak ditentukan oleh pada tahap mana tim berada. 53 tim yang masuk pada tahap performing memiliki rata-rata penugasan yang berbeda-beda. Ada yang baik dan ada yang buruk. Timtim tersebut telah bekerja secara efisien namun keefisienan itu belum tentu menghasilkan output yang baik. Kualitas output yang dihasilkan lebih tergantung pada kemampuan tiap tim. Ini terbukti dari hasil penelitian yang menunjukkan bahwa hasil penugasan pada metode McGrath lebih tinggi dibanding yang lain karena pembentukan tim lebih mengutamakan keseimbangan kemampuan antar tim. 
Ketika dilakukan penelitian terhadap masing-masing metode pembentukan tim, memang pada metode sendiri ++ terjadi korelasi antara tahapan pembentukan tim dengan hasil penugasan, namun korelasi yang terjadi adalah korelasi yang tidak cukup kuat. Tim yang terbentuk dengan metode McGrath memiliki kualitas yang cenderung sama antar tim, sehingga kecenderungannya tahapan pembentukan dari tim-tim tersebut sama, yang dalam penelitian ternyata masuk pada tahap performing, dan hasil penugasannya cenderung sama baik. Tetapi, pada pembentukan tim oleh mahasiswa (metode sendiri) kualitas antar tim tidak sama. Ada yang tinggi dan ada yang rendah. Maka, hasil penugasan pun lebih beragam. Tim-tim yang ada juga tidak mendapat treatment terkait penugasan. Sehingga tidak ada standar untuk menilai kerjasama tim. Maka, dengan kualitas yang berbeda antar tim dan tidak adanya standar untuk melakukan penilaian, tim-tim menilai proses pembentukan tim mereka hanya berdasarkan perasaan mereka. Tidak mengherankan mereka memandang bahwa tim mereka telah melakukan kerjasama dengan baik. Sehingga ketika kerjasama tim-tim tersebut diklasifikasikan ke masing-masing kriteria tahapan pembentukan tim, hasil yang didapat adalah cenderung sama. Setelah diteliti lebih lanjut, tim-tim tersebut sebagian besar masuk pada tahap performing walau hasil penugasan mereka beragam.

Kebalikan dari metode sendiri, pada metode sendiri ++ tim-tim diberi berbagai treatment oleh dosen, sehingga tim-tim tersebut memiliki standar untuk membandingkan apa yang mereka rencanakan dengan apa yang telah mereka lakukan. Maka, penilaian atas kerjasama mereka berdasarkan apa yang terjadi. Oleh karena itu, pada metode ini terjadi korelasi yang tidak cukup kuat antara tahapan pembentukan tim dengan hasil penugasan.

\section{SIMPULAN}

Dari hasil penelitian, dapat ditarik simpulan: tidak terdapat perbedaan hasil kinerja tim antara tim yang anggotanya dipilih sendiri tanpa intervensi dosen, tim yang anggotanya dipilih sendiri oleh mahasiswa dengan intervensi dosen untuk tahapan selanjutnya (tahap input pada McGrath's model), dan tim yang didesain oleh dosen dengan aplikasi McGrath's model; hasil penugasan tim yang didesain oleh dosen dengan aplikasi McGrath's model berbeda dengan hasil penugasan tim yang anggotanya dipilih sendiri tanpa intervensi dosen dan tim yang anggotanya dipilih sendiri oleh mahasiswa dengan intervensi dosen untuk tahapan selanjutnya (tahap input pada McGrath's model); Tim yang didesain oleh dosen dengan aplikasi McGrath's model memperoleh rata-rata hasil penugasan tertinggi dibanding kedua metode lanilla; tidak terdapat hubungan antara hasil kinerja tim dengan hasil penugasan, baik secara keseluruhan maupun dari masing-masing metode pembentukan tim; tidak terdapat hubungan antara tahapan pembentukan tim dengan hasil penugasan secara keseluruhan, namun terjadi hubungan yang tidak kuat pada metode pembentukan tim yang anggotanya dipilih sendiri oleh mahasiswa dengan intervensi dosen untuk tahapan selanjutnya (tahap input pada McGrath's model); metode yang paling efektif dari ketiga metode yang telah diaplikasikan adalah metode pembentukan tim oleh dosen dengan aplikasi McGrath's Model karena dengan metode ini kualitas tim yang terbentuk memiliki kinerja dan masuk ke dalam tahapan pembentukan yang sama dengan metode lainnya namun mampu menghasilkan nilai penugasan tertinggi dibandingkan metode lanilla; aplikasi McGrath's Model memberi kesempatan pada para mahasiswa untuk dapat bekerjasama dengan rekan yang berbeda, yang mungkin belum mereka kenal dekat. Sehingga, metode ini lebih bisa mengoptimalkan soft skill dalam hal teamwork.

Penelitian ini masih memiliki keterbatasan yaitu mata kuliah dari kelas yang dijadikan objek penelitian merupakan mata kuliah yang berbobot 2 sks sehingga waktu tiap pertemuan hanya 100 menit. Ini membuat desain penelitian kurang bisa dilaksanakan secara maksimal karena keterbatasan waktu. Oleh karena itu, disarankan untuk penelitian selanjutnya dilakukan pada mata kuliah yang memiliki waktu lebih panjang agar responden lebih bisa mengikuti desain penelitian secara maksimal dan lebih bisa diarahkan dalam pengisian kuesioner. Selain itu, penelitian juga dapat dilakukan pada 
universitas lain yang memiliki jumlah mahasiswa lebih banyak, dimana lebih besar kemungkinan antar mahasiswa tidak saling kenal.

\section{DAFTAR PUSTAKA}

Active Transformation (2007). Membangun tim yang solid. Diakses tanggal 6 Maret 2009 dari http://activetransformation.blogspot.com/2007/12/membangun-tim-yang-solid.html.

Aczel, A. D. (2002). Complete business statistics, $5^{\text {th }}$ ed., New York: McGraw-Hill.

American Institute of Certified Public Accounting (AICPA). (2005). AICPA Core competency frame work for entry into the accounting profesion. Retrieved from http://www aicpa.org/edu/corecomp.html.

Barrick, M., and M. Mount (1991). The big five personality dimensions and job performance: A metanalysis. Personnel Psychology, 44, 1-26.

Bateman, B., C., Wilson, and D. Bingham (2002). Team effectiveness - development of an audit questionnaire. The Journal of Management Development, 21 (3), 215-226.

Bryant, S. M. (2001). A blueprint for an AIS consulting course. Journal of Information System, 15 (1), 19-34.

Bryan, S., and Albrings. (2006). Effective team building: Guidance for accounting educators. Journal of Accounting Education, 21, 241-265.

Burch, C. (1997). Creating a two-tiered portfolio rubric. English Journal, 86, 55-58.

Champion, J. J., G. Medsker, and A. Higgs. (1993). Relations between work group characteristics and effectiviness: Implications for designing effective work groups. Personnel Psychology, 46, 823-850.

Chang, R. Y. (1999). Membangun tim yang dinamis: Seri panduan praktis no. 8, Jakarta: Gramedia.

Chang, R. Y. (1999). Sukses melalui kerjasama tim: Seri panduan praktis, Jakarta: Gramedia.

Cockriel, I. (2001). Forming instructional groups from sociometric data. Educations, 93 (4), 393-395.

Colbeck, C., S. Campbell, and S. Bjorklund. (2000). Grouping in the dark: What college student learn from group projects. The Journal of Higher Educations, 10, 95-111.

Danko, K., J. Duke, and D. Franz. (1992). Predicting student performance in accounting classes. Journal of Education for Business, 270-274.

Dudley, M. (2001). Speaking my mind. English Journal, 90, 19-20.

Feitctner, S., and E. Davis. (1992). Why some groups fail: A survey of student' experiences with learning groups. In collaborative learnings: A sourcebook for higher education, edited by A. 
Goodsell, M. Maher, and V. Tinto. University Park, PA: National Center on Postsecondary Teaching, Learning and Assesment.

Greenberg, J. (1996). Managing behavior in organizations. Upper Saddle River, New Jersey: Prentice Hall.

Grudnitski, G. (1997). A forecast of achievement from student profile data. Journal of Accounting Education, 15 (4), 549-558.

Hackman, J. R. (1987). The design of work teams. In handbook of organizational behavior, edited by J. W. Lorsch. Englewood Cliffs, New Jersey: Prentice Hall.

Hermana. (2008). Hard skill dan soft skill. Diakses tanggal 21 Januari 2009 dari http://nustaffsite.gunadarma.ac.id/blog/bhermana/2008/05/19/hard-skills-dan-soft skills/.

Hoevemeyer, V. (1993). How effective is your time? Training and Development, (September), 67-71.

Holcomb, J., and R. Ruffer. (2000). Using a term-long project sequence in introductory statistics the American statistician, 54, 49-53.

Jex, S. (2002). Organizational pscyhology: A scientific-practitioner approach, New York: John Wiley $\&$ Sons, Inc.

Katzenbach, J., and C. K. Smith. (1999). The wisdom of teams: Creating the high performance organization, New York: Harver Collins Publishers, Inc.

Koppenhaver, G., and C. Shrader. (2003). Structuring the classroom for performance: Cooperative learning with instructor - assigned teams. Decisions Sciences, 1 (1), 1-15.

Lancaster, K., and C. Strand. (2001). Using the team learning model in a managerial accounting class: An experiment in cooperative learning. Issues in Accounting Education, 16 (4), 549567.

Lasahido, I. (2008). Membangun tim yang efektif. Diakses tanggal 27 Februari 2009 dari http://www.bppk.depkeu.go.id/webpegawai/index.php?option=com_docman\&task=catview\& gid=52\&Itemid $=61$.

Latane, B., and S. Nida. (1980). Social impact theory and group influence: A social engineering perspective. In Psychology of group influence, edited by P. B. Paulus. Hillsdale, New Jersey: Lawrence Erlbaum Associates.

Lencioni, P. (2005). The five dysfunctions of a team: A field guid for leders, managers, and facilitators, San Fransisco, CA: Jossey-Bass.

Maddux, R. B. (2001). Team Building ed2: Kiat membangun tim yang handal. Diterjemahkan oleh Hananto, K.P, Jakarta: Esensi, divisi penerbit Erlangga.

Manchester Open Learning Staff. (1993). Achieving goals through teamwork: Management action guides. United Kingdom: Kogan Page.

Markel, M. (1998). Technical communication: Situations and strategies, $5^{\text {th }}$ ed., New York: St. Martins Press. 
McClough, A., and S. Rogelberg. (2003). Selection in teams: An exploration of team work knowledge, skill, and ability test. International Journal of Selection an Assessment, 11 (1), 56-66.

McGrath, J. (1964). Social psychology: A brief introduction, New York: Holt.

Papu, J. (2004). Team work. Diakses tanggal 6 Maret 2009 dari http://www.epsikologi.com/epsi/industri_detail.asp?id=161.

Pelled, L., K. Ein Eisenhardt, and K. Xin. (1999). Exploring the black box: An analysis of work group diversity, conflict, and performance. Administrative Science Quarterly, 44, 1-28.

Prast, D. (2008). Kualitas personal yang dibutuhkan dalam dunia kerja. Diakses tanggal 16 Januari 2009 dari http://www.dimasprast.com/2008/06/kualitas-personal-yang-dibutuhkan dalam.html.

Ravenscroft, S., F. Buckless, G. McCombs, and G. Zuckerman. (1995). Incentives in student team learning: An experiment in cooperative group learning. Issues in Accounting Education, 10 (Spring), $97-109$.

Robbins, S. P. (2006). Perilaku organisasi, edisi kesepuluh. Diterjemahkan oleh Benyamin, M., Jakarta: PT Indeks Kelompok Gramedia.

Robbins, S. P. (1997). Essentials of organizational behavior, Upper saddle river, New Jersey: Prentice Hall.

Santosa, P. B., dan Ashari. (2005). Analisis statistik dengan microsoft excel dan spss, Yogyakarta: Andi.

Sekaran. (2003). Research methods for business: A skill building approach, New York: John Wiley \& Sons, Inc.

Smith, M. K. (2005). 'Bruce W. Tuckman - forming, storming, norming and performing in groups, the encyclopaedia of informal education. Diakses tanggal 6 Maret 2009 dari http://www.infed.org/thinkers/tuckman.html.

Speck, B. (2002). Facilitating students' collaborative writing. ASHE-ERIC Higher Education Report, 28 (6), San Fransisco, CA: Jossey-Bass.

Sugiyono. (2007). Metode penelitian bisnis, Bandung: Alfabeta.

Tin, Se. (2007). Membentuk soft skill mahasiswa akuntansi melalui effective team building dalam ruang kelas: sebuah aplikasi McGrath's Model. Paper dipresentasikan pada Simposium Nasional Akuntansi 10, Universitas Hasanudin, Makasar. 